\title{
Heterogeneity of the humoral immune response following Staphylococcus aureus bacteremia
}

\author{
N. J. Verkaik • H. A. Boelens • C. P. de Vogel • \\ M. Tavakol • L. G. M. Bode $\cdot$ H. A. Verbrugh • \\ A. van Belkum • W. J. B. van Wamel
}

Received: 29 January 2010 / Accepted: 1 February 2010 / Published online: 26 February 2010

(C) The Author(s) 2010. This article is published with open access at Springerlink.com

\begin{abstract}
Expanding knowledge on the humoral immune response in Staphylococcus aureus-infected patients is a mandatory step in the development of vaccines and immunotherapies. Here, we present novel insights into the antibody responses following $S$. aureus bacteremia. Fifteen bacteremic patients were followed extensively from diagnosis onwards (median 29 days, range 9-74). S. aureus strains (median 3, range 1-6) and serial serum samples (median 16, range 6-27) were collected. Strains were genotyped by pulsed-field gel electrophoresis (PFGE) and genes encoding 19 staphylococcal proteins were detected by polymerase chain reaction (PCR). The levels of IgG, $\operatorname{IgA}$, and IgM directed to these proteins were determined using bead-based flow cytometry. All strains isolated from individual patients were PFGE-identical. The genes encoding clumping factor (Clf) $\mathrm{A}, \mathrm{ClfB}$, and iron-responsive surface-determinant (Isd) A were detected in all isolates. Antigen-specific IgG levels increased more frequently than IgA or IgM levels. In individual patients, different proteins induced an immune response and the dynamics clearly differed. Anti-ClfB, anti-IsdH, and anti-fibronectin-binding protein A IgG levels increased in 7 of 13 adult patients $(p<$ $0.05)$. The anti-IsdA IgG level increased in 12 patients (initial to peak level: $1.13-10.72$ fold; $p<0.01$ ). Peak level was reached 7-37 days after diagnosis. In a bacteremic 5-day-old newborn, antistaphylococcal IgG levels declined
\end{abstract}

N. J. Verkaik $(\bowtie) \cdot$ H. A. Boelens $\cdot$ C. P. de Vogel $\cdot$ M. Tavakol

L. G. M. Bode $\cdot$ H. A. Verbrugh · A. van Belkum •

W. J. B. van Wamel

Department of Medical Microbiology and Infectious Diseases,

Erasmus MC,

's Gravendijkwal 230,

3015 CE Rotterdam, The Netherlands

e-mail: n.j.verkaik@erasmusmc.nl from diagnosis onwards. In conclusion, each bacteremic patient develops a unique immune response directed to different staphylococcal proteins. Therefore, vaccines should be based on multiple components. IsdA is immunogenic and, therefore, produced in nearly all bacteremic patients. This suggests that IsdA might be a useful component of a multivalent staphylococcal vaccine.

\section{Introduction}

Staphylococcus aureus is a leading cause of nosocomial bloodstream infections [1]. Risk factors for these invasive infections are intravascular catheters and nasal carriage [2]. Nasal carriers have a three- to four-fold increased risk of acquiring a nosocomial bacteremia as compared to noncarriers [3, 4]. Bacteremic patients can develop serious complications, such as infective endocarditis, prosthetic device infection, septic arthritis, deep tissue abscesses, and vertebral osteomyelitis [5-8]. S. aureus bloodstream infections extend the length of hospital stay and increase antibiotic usage, costs, and mortality; approximately 20$30 \%$ of the patients die $[1,9,10]$. Worldwide, the increasing resistance of $S$. aureus isolates to various antibiotics complicates the treatment of bacteremia [11, 12]. Meanwhile, the number of new approved antimicrobial agents has decreased over the last several years [13]. Therefore, alternative strategies to prevent and treat $S$. aureus bacteremia, such as vaccines and immunotherapy, are urgently required [14]. For the development of these alternative strategies, expanding knowledge on the humoral immune response in $S$. aureus-infected patients is a mandatory step. In this study, we generate novel insights in the antibody responses following $S$. aureus bacteremia. 


\section{Materials and methods}

Patients, definitions, and setting

Fifteen patients (13 adults and two children, Table 1) admitted to the Erasmus MC, Rotterdam, The Netherlands, from March to June 2008 were followed from the diagnosis of $S$. aureus bacteremia until the end of hospital stay (range 9-74 days, median 29 days). Bacteremia was defined upon isolation of $S$. aureus from at least one blood culture set. From these patients, a total of 44 methicillinsusceptible $S$. aureus strains were collected for routine culture. The median number of collected strains per patient was 3 (range 1-6). The $S$. aureus strains were isolated from blood, sites of infection, and, if applicable, other sites. Furthermore, serial serum samples were collected (leftover material). The median number of days between the first positive blood culture and the first sampling of serum was 1 day (range 0-20 days). From each patient, at least 6 (median 16, range 6-27) serum samples were collected, leading to a total of 232 serum samples. The time between the first positive blood culture and the first negative (control) blood culture ranged from 1-6 days (median 2 days; excluding one patient for whom no additional blood culture was obtained).
Sera from four non-S. aureus bacteremic patients were used as controls. These four patients were diagnosed with a Klebsiella pneumoniae, Proteus mirabilis, coagulasenegative staphylococcus (CNS), or Enterococcus faecium bacteremia. The number of days between the first positive blood culture and the first sample ranged from 0 to 2 days. Per patient, 12-26 (median 16) serum samples were collected. The follow-up time ranged from 22 to 50 days (median 29 days).

Patients were treated with antibiotics according to hospital guidelines under the supervision of Infectious Disease consultants. Catheters were removed if they were the suspected origin of the bacteremia. The Medical Ethics Committee of the Erasmus MC, Rotterdam, The Netherlands, approved the study (MEC 2007-106, addendum 2).

S. aureus identification, detection of virulence genes, and genotyping

S. aureus was identified based on colony and microscopic morphology and Slidex Staph Plus agglutination testing (bioMérieux). The identification of $S$. aureus was confirmed by spa polymerase chain reaction (PCR) [15]. The isolates were screened for genes encoding important staphylococcal proteins: the microbial surface components recognizing

Table 1 Characteristics of the patients and their bacteremia

\begin{tabular}{|c|c|c|c|c|c|c|}
\hline Patient no. & Sex & Age (years) & Underlying disease & $\begin{array}{l}\text { Origin of } S . \text { aureus } \\
\text { bacteremia }^{\text {a }}\end{array}$ & Outcome & $\begin{array}{l}\text { No. of } \\
\text { samples }\end{array}$ \\
\hline 1 & $\mathrm{~F}$ & 21 & Kidney transplantation & Catheter related & Survived & 27 \\
\hline 2 & M & 71 & B-cell non-Hodgkin lymphoma & Catheter related & Survived & 8 \\
\hline 3 & M & 21 & HIV positive & Pyomyositis & Survived & 14 \\
\hline 4 & $\mathrm{~F}$ & 74 & $\begin{array}{l}\text { DM II, cortisol-producing tumor } \\
\text { of the adrenal gland }\end{array}$ & $\begin{array}{l}\text { Abscess hand } \\
\text { (catheter related) }\end{array}$ & Survived & 26 \\
\hline 5 & M & 60 & DM II and cardiovascular disease & Unknown & Deceased $^{\mathrm{b}}$ & 9 \\
\hline 6 & M & 75 & DM II and cardiovascular disease & Diabetic foot & Survived & 19 \\
\hline 7 & M & 63 & Cardiovascular disease & $\begin{array}{l}\text { Osteomyelitis sternum } \\
\text { (after CABG) }\end{array}$ & Survived & 23 \\
\hline 8 & M & 69 & Esophageal carcinoma & Cellulitis knee & Survived & 7 \\
\hline 9 & M & 37 & Myocarditis & $\begin{array}{l}\text { Infected thrombus } \\
\text { (catheter related) }\end{array}$ & Survived & 18 \\
\hline 10 & M & 64 & Bronchus carcinoma & Unknown & Survived & 22 \\
\hline 11 & M & 63 & None & $\begin{array}{l}\text { Spondylodiscitis } \\
\text { (dental origin) }\end{array}$ & Survived & 8 \\
\hline 12 & $\mathrm{~F}$ & 64 & Mamma carcinoma T-cell lymphoma & Catheter related & Survived & 16 \\
\hline 13 & $\mathrm{~F}$ & 47 & IV drug abuse Hepatitis C & Chronic osteomyelitis arm & $\begin{array}{l}\text { Deceased (MOF } \\
\text { by sepsis) }\end{array}$ & 9 \\
\hline 14 & M & 5 days & Congenital disorders & $\begin{array}{l}\text { Infected head wound } \\
\text { (catheter related) }\end{array}$ & Survived & 20 \\
\hline 15 & M & 2 years 11 months & Medulloblastoma & Catheter related & Deceased $^{\mathrm{b}}$ & 6 \\
\hline
\end{tabular}

M, male; F, female; DM, diabetes mellitus; CABG, coronary artery bypass graft; MOF, multiple organ failure

${ }^{a}$ The origin of the bacteremia was recorded on the medical charts by the Infectious Disease consultant

${ }^{\mathrm{b}}$ Cause of death not related to bacteremia according to post-mortem examination 
Fig. 1 Dendogram of the pulsed-field gel electrophoresis (PFGE) data of 44 Staphylococcus aureus strains isolated from 15 bacteremic patients. Strains isolated from individual patients are clonally related

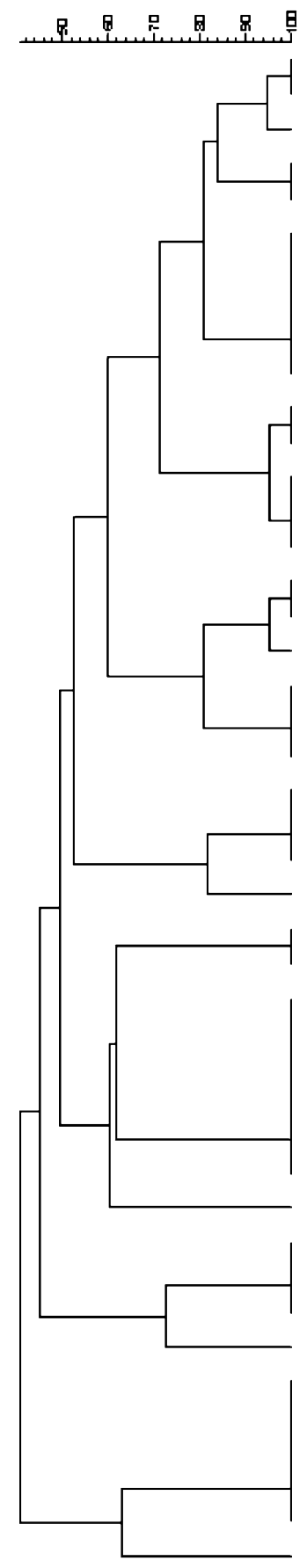

Pt No.

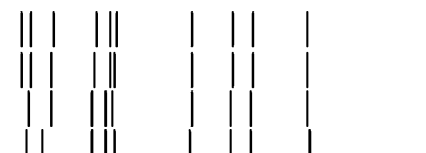

Material

Peripheral blood culture

Catheter exit site

Wound fluid groin

Wound fluid penis

Elister penis

Fluid from sternal wound

Catheter-drawn blood culture

Peripheral blood culture

Fluid pleuraempyema

Sternal tissue

Catheter exit site

Rectum

Peripheral blood culture

Peripheral blood culture

Peripheral blood culture

Peripheral blood culture

Wound fluid toot

Foot tissue

Eronchoalveolar lavage

Peripheral blood culture

Peripheral blood culture

Peripheral blood culture

Wound fluid right arm

Wound fluid left am

Catheter-dramm blood culture Blood culture

Pus from abscess spondylodiscitis

Peripheral blood culture

Pus from abscess back (L5)

Pus from abscess schoulder

Pus from abscess back (L4)

Groin tissue

Wound fluid back ( $L 3$ )

Peripheral blaod culture

Catheter-dramn blood culture

Peripheral blood culture

Bone marrow transplant

Catheter-dram blood culture

Peripheral blaod culture

Catheter-dramn blood culture

Wound fluid hand

Catheter-dramn blood culture

Sputum

Peripheral blood culture adhesive matrix molecules (MSCRAMMs), staphylococcal enterotoxins (SEs), and immunomodulatory proteins [1620]. Sequences specific for clumping factor A and B (ClfA and $\mathrm{ClfB}$ ), S. aureus surface protein G (SasG), ironresponsive surface determinant $\mathrm{A}$ and $\mathrm{H}$ (IsdA and $\mathrm{IsdH}$ ), fibronectin-binding protein $\mathrm{A}$ and $\mathrm{B}$ (FnbpA and FnbpB), serine-aspartate dipeptide repeat protein $\mathrm{D}$ and $\mathrm{E}$ (SdrD and SdrE), SEA, SEB, SEI, SEM, SEO, SEQ, toxic shock syndrome toxin (TSST-1), staphylococcal complement inhibitor (SCIN), extracellular fibrinogen-binding protein (Efb), and chemotaxis inhibitory protein of S. aureus (CHIPS) were detected. Primers for isdA (Fw, CTGCGTCAGCTAATGTA GGA; Rv, TGGCTCTTCAGAGAAGTCAC), isdH (Fw, TCTGCTGGTGGATACTGTTG; Rv, TGCCAGTGAGAC TTGTATCG), sasG (Fw, GGCCACTTGGATGAGTTGGT; Rv, CGAAGAGCCAGTGGATGATG), $s d r D$ (Fw, CGGA GCTGGTCAAGAAGTAT; Rv, TGCCATCTGCGTC TGTTGTA), and efb (Fw, GAAGGATACGGTCCAAGA GA; Rv, TGTGGACGTGCACCATATTC) were newly designed. Other genes were detected by PCR as described 


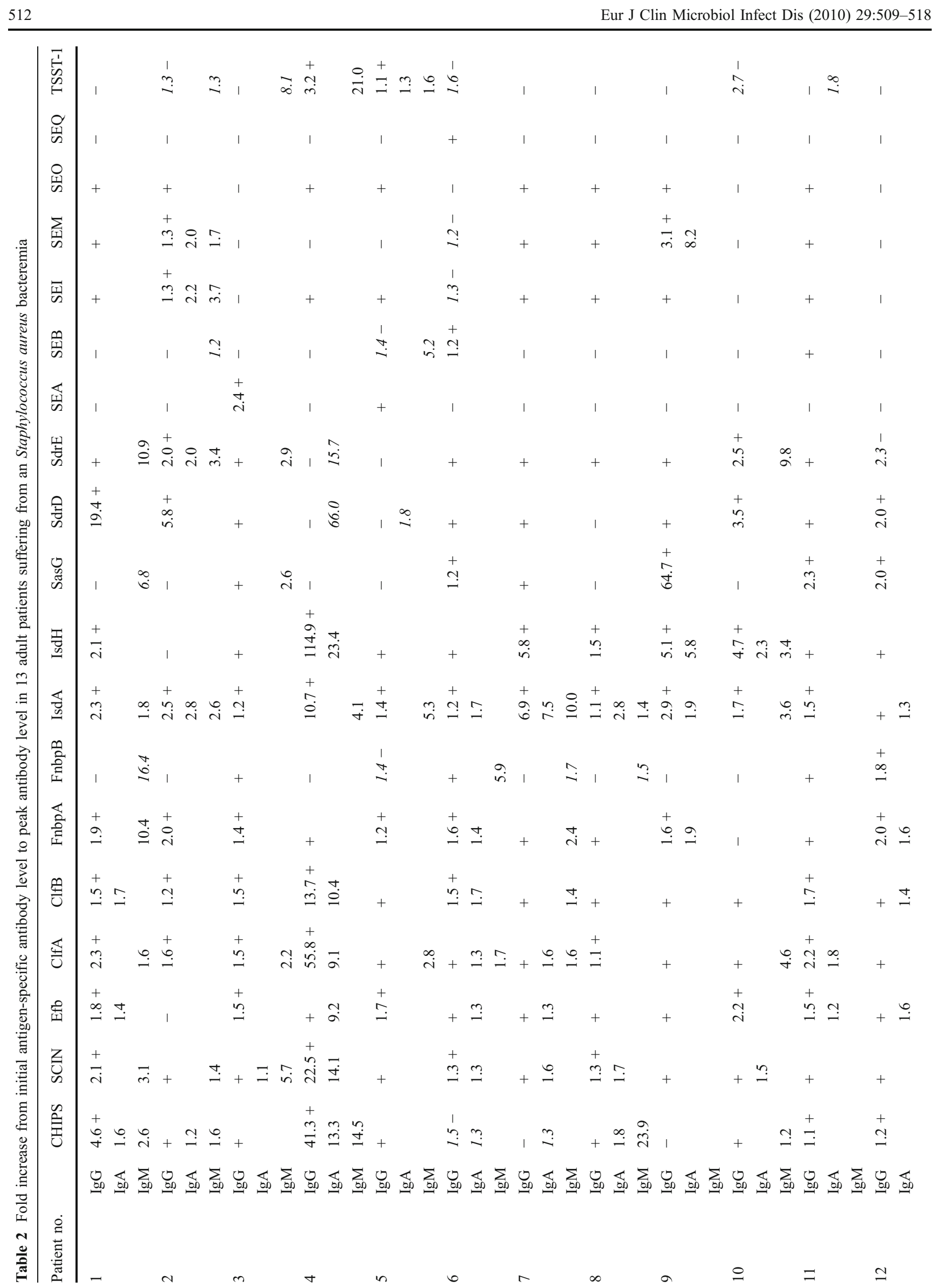

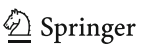




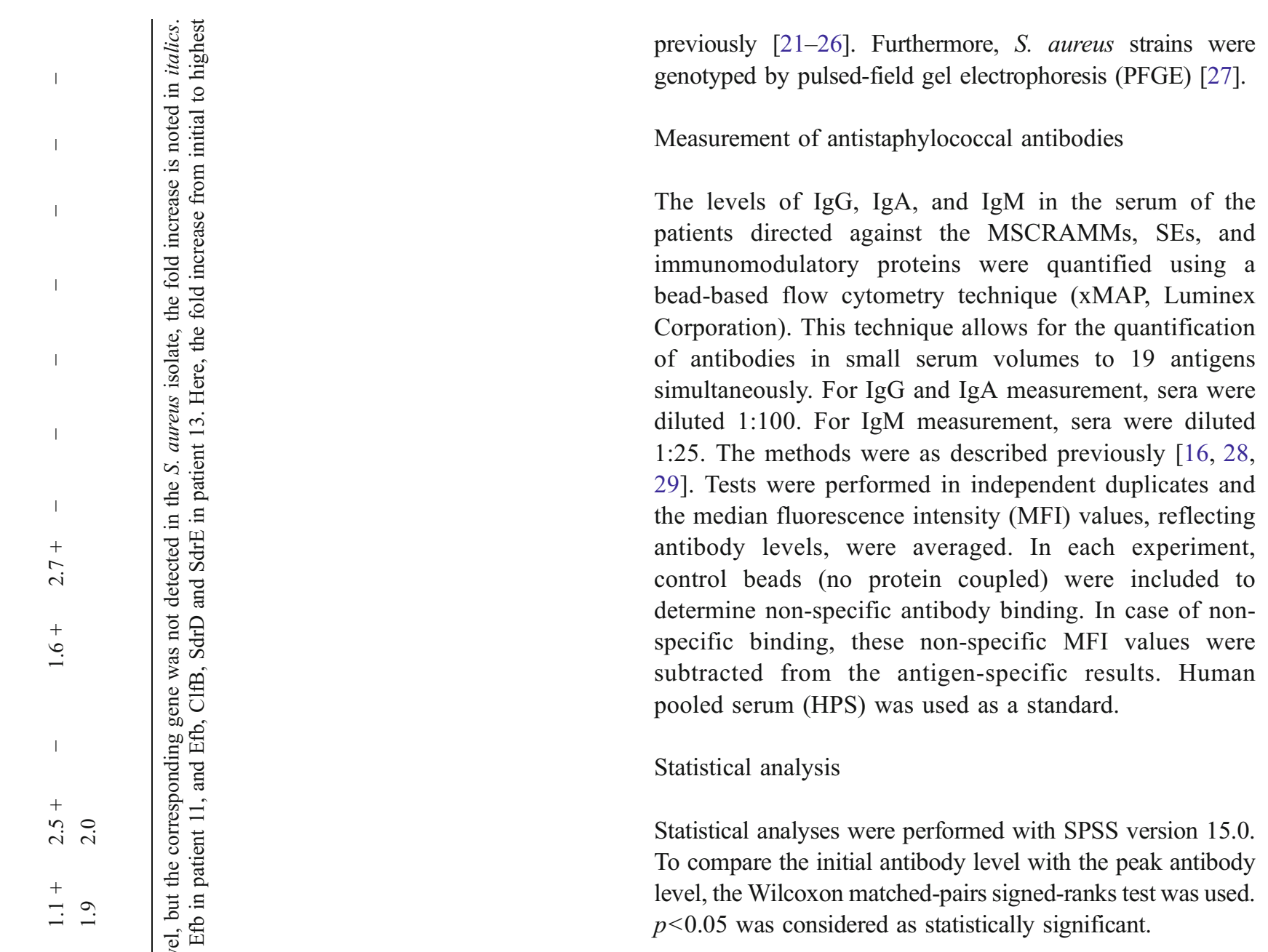

\section{Results}

PFGE analysis

PFGE analysis was performed for all $S$. aureus strains isolated. A dendogram of the PFGE data (Fig. 1) shows the overall lack of relatedness among the strains from different patients, with the exception of patients 4 and 5 . There was no epidemiological relationship between these two patients. All $S$. aureus strains isolated from an individual patient were genotypically indiscriminate ( $>95 \%$ relatedness) and clustered in the dendogram; only in the case of patient 9 were the PFGE patterns of the strains slightly different.

Detection of virulence genes

Based on PCR analyses, $c l f A$, clfB, and isd $A$ were ubiquitous in all 44 isolates obtained from the 15 bacteremic patients. scn, efb, fnbA, and isdH were detected in $>90 \%$ of the isolates. sdrD, sdrE, sasG, sei, seo, sem, chp, and fnbB were detected in $35(80 \%), 33(75 \%), 30(68 \%), 28(64 \%), 28$ 

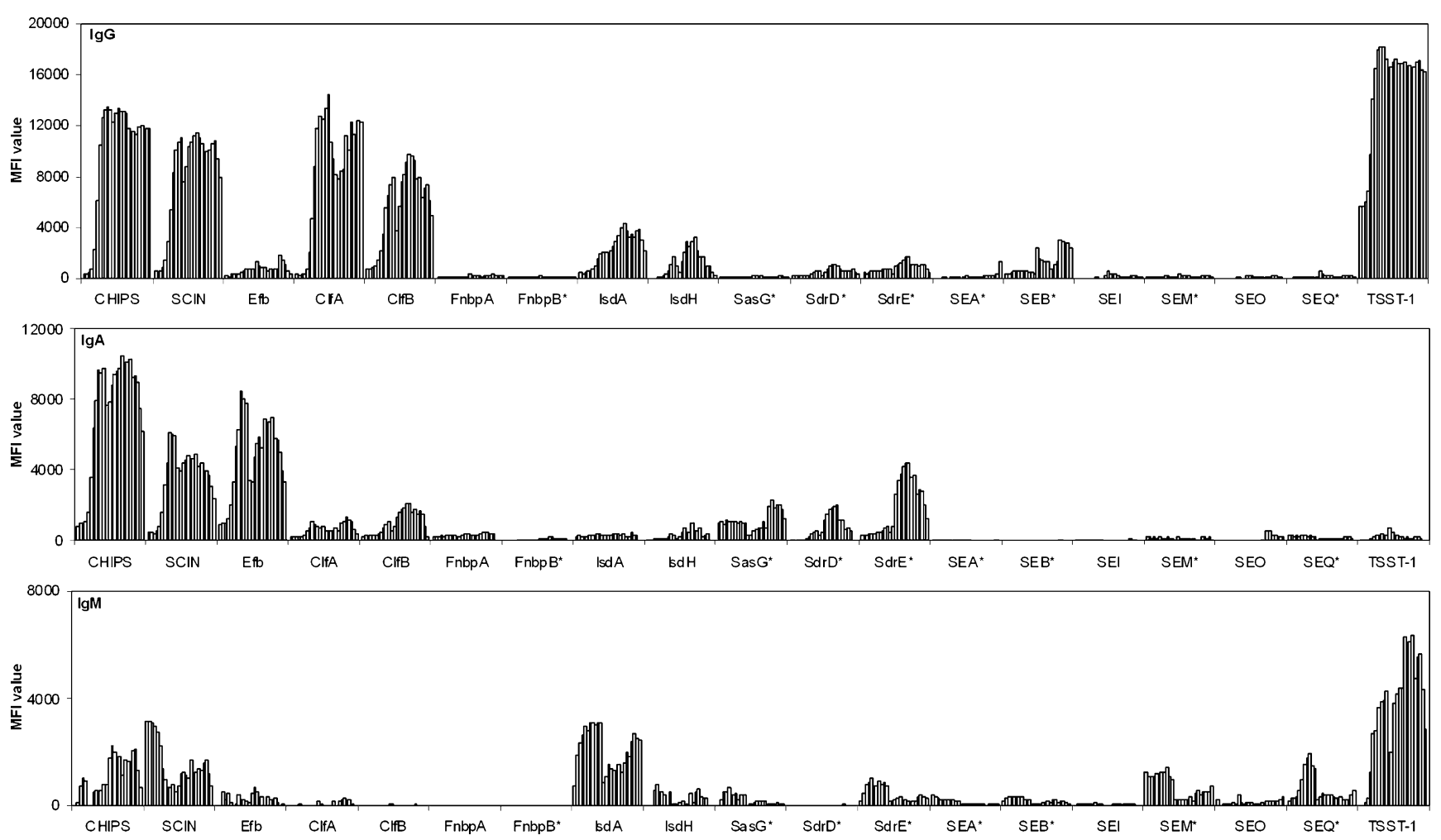

Fig. 2 Course of IgG, IgA, and IgM levels directed to 19 S. aureus proteins following bacteremia. The results are shown for patient 4 . Each bar represents a serum sample on a separate day. The time period between the first and last serum sample is 58 days. *The corresponding gene was not detected in the $S$. aureus isolate
(64\%), $23(52 \%), 23(52 \%)$, and $14(32 \%)$ of the isolates, respectively. Less than $20 \%$ of the isolates harbored sea, seb, seq, and tst-1. Overall, all strains isolated from a single patient (PFGE-identical) harbored the same virulence genes, with two exceptions. In patient $6, s c n$ was detected only in the strain isolated from foot tissue, but not in the strains isolated from blood and the superficially cultured wound of the foot. In patient 15 , sas $G$ was detected only in the strain isolated from catheter-drawn blood, but not in the strain isolated from peripheral blood or bone marrow (Fig. 1). An overview of the presence of virulence genes in $S$. aureus strains per patient is shown in Table 2.

\section{Antistaphylococcal antibodies}

The levels of IgG, IgA, and IgM directed to 19 S. aureus proteins were measured from diagnosis bacteremia onwards. In Fig. 2, the changes in antistaphylococcal IgG, $\operatorname{IgA}$, and IgM levels after diagnosis bacteremia are shown for one patient (patient 4). For all patients, the course of the antibody response was determined. If there was an increase in antibody level in the consecutive serum samples, the fold increase from initial antibody level (as measured in the first obtained serum sample) to peak level was calculated. An overview for the 13 adult patients is shown in Table 2. In each patient, increases in antistaphylococcal antibody levels directed to different $S$. aureus proteins were observed. Antibody responses were directed mainly to the immunomodulatory proteins and MSCRAMMs. An increase in anti-IsdA IgG level was detectable in 12 out of $13(92 \%)$ adult bacteremic patients (Fig. 3; with the exception of patient 12). Some patients showed a small decline in antiIsdA IgG level before the increase. The median increase from initial to peak level was 1.71-fold (range 1.13-10.70fold, $p<0.01)$. The number of days to reach anti-IsdA IgG peak levels ranged between 7 and 37 days (median 21 days). It appeared that patients with a site of infection other than catheter-related (patients 6, 7, 8,11, and 13) reached higher levels, but the anti-IsdA IgG peak level was high in patient 2 as well (Fig. 3). In Table 3, the dynamics of the $\operatorname{IgG}$ responses directed against all immunomodulatory proteins and MSCRAMMs are summarized per $S$. aureus protein.

An increase in antigen-specific IgA was detected less frequently than an increase in IgG. In 7 out of 13 patients with a gene-positive isolate, the anti-IsdA, antiSCIN, and anti-Efb IgA level increased. Peak levels were reached between 6 and 34 days. In not a single patient was a rise in anti-FnbpB, SasG, SEA, SEB, SEO, or SEQ IgA level detected. Increases in IgM were detected the least often out of the three antibody isotypes 
(Table 2). For patients 9 and 11, most antigen-specific IgM levels showed a decrease.

In the two children, the antibody responses were quite different from the antibody responses in adults. In the 5-day-old newborn (patient 14), a continuous decline in antigen-specific (maternal) IgG for 18 out of 19 proteins was seen from the moment of diagnosis. This could be due to the extensive consumption of maternal antibodies in the absence of de novo antibody synthesis (Fig. 4). The level of IgM increased for CHIPS (isolate chp-negative), SCIN, SasG, SdrD, SdrE, SEM, SEO, and SEQ (seq-negative). The level of IgA was around zero. In the 2-year-old child (patient 15), an increase was noted for IgG directed to IsdA and CHIPS only. IgM increased for SCIN, ClfA, SdrD,
SdrE (isolate $s d r D$ - and $s d r E$-negative), SEI, SEM, SEO, and TSST-1 (tst-negative).

In the four control patients who did not suffer from an $S$. aureus bacteremia, the CNS-infected patient showed a 1.2fold increase in anti-CHIPS IgG level (from MFI 13333 to MFI 16002), and the $K$. pneumoniae-infected patient showed a 1.4-fold increase in anti-ClfB IgG level (from MFI 5647 to MFI 8058). Furthermore, no increases in antistaphylococcal antibody levels were noted. This shows that there is little inter-species cross-reactivity. However, in the patients suffering from an $S$. aureus bacteremia, a rise in antibody level while the corresponding gene was not present in the $S$. aureus isolate was observed in 23 of 179 increases (12.8\%; Table 2).
Fig. 3 Course of anti-IsdA IgG levels following $S$. aureus bacteremia in different adult patients

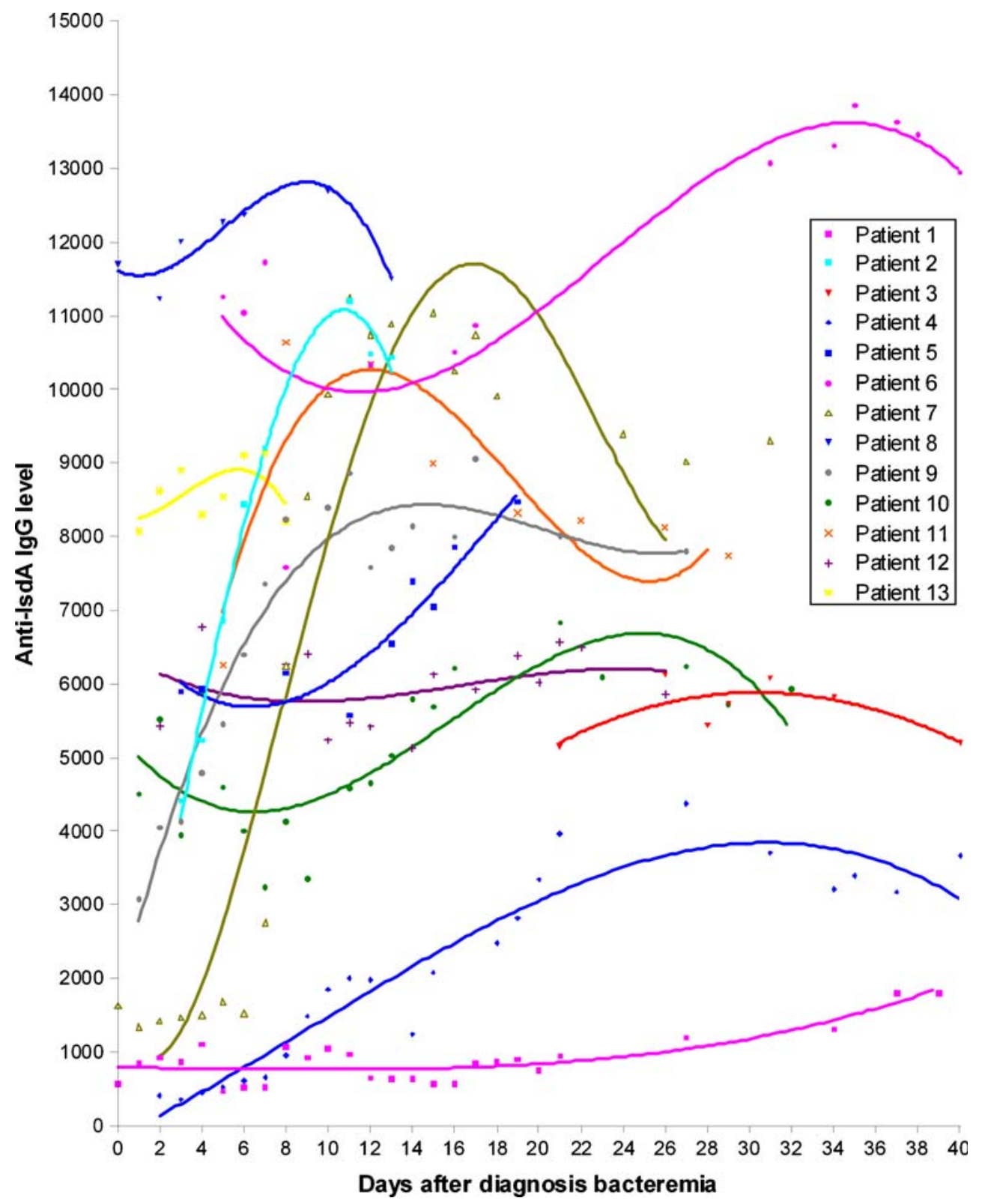


Table 3 Dynamics of the antistaphylococcal IgG response during bacteremia

\begin{tabular}{|c|c|c|c|c|c|}
\hline Protein & $\begin{array}{l}\text { No. of adult patients with } \\
\text { gene-positive isolates (\%) }\end{array}$ & $\begin{array}{l}\text { No. of adult patients with } \\
\text { increase in IgG level (\%) }\end{array}$ & $\begin{array}{l}\text { Median fold increase from } \\
\text { initial to peak level (range) }\end{array}$ & $\begin{array}{l}\text { Median no. of days to } \\
\text { reach peak level (range) }\end{array}$ & $p$-value ${ }^{\mathrm{d}}$ \\
\hline CHIPS & 9/13 (69\%) & $4 / 9(44 \%)$ & $2.9(1.1-41.3)$ & $25(11-27)$ & - \\
\hline SCIN & $13 / 13(100 \%)$ & $5 / 13(38 \%)$ & $1.3(1.1-22.5)$ & $21(5-42)$ & $<0.05$ \\
\hline $\mathrm{Efb}$ & $12 / 13(92 \%)$ & $6 / 12(50 \%)$ & $1.7(1.5-2.1)$ & $24(14-44)$ & $<0.05$ \\
\hline ClfA & $13 / 13(100 \%)$ & $6 / 13(46 \%)$ & $1.9(1.1-55.8)$ & $19(10-40)$ & $<0.05$ \\
\hline ClfB & $13 / 13(100 \%)$ & $7 / 13(54 \%)$ & $1.5(1.2-13.7)$ & $28(11-50)$ & $<0.05$ \\
\hline FnbpA & $11 / 13(85 \%)$ & 7/11 (64\%) & $1.6(1.4-2.0)$ & $27(11-42)$ & $<0.05$ \\
\hline FnbpB & $4 / 13(31 \%)$ & $1 / 4(25 \%)$ & $1.8^{\mathrm{b}}$ & $23^{\mathrm{c}}$ & - \\
\hline IsdA & $13 / 13(100 \%)$ & $12 / 13(92 \%)$ & $1.7(1.1-10.7)$ & $21(7-35)$ & $<0.01$ \\
\hline IsdH & $12 / 13(92 \%)$ & $7 / 12(58 \%)$ & $4.7(1.5-114.9)$ & $15(7-34)$ & $<0.05$ \\
\hline SasG & $6 / 13(46 \%)$ & $4 / 6(67 \%)$ & $2.1(1.2-64.7)$ & $23(11-42)$ & - \\
\hline SdrD & $10 / 13(77 \%)$ & $5 / 10(50 \%)$ & $4.7(2.0-19.4)$ & $22(11-27)$ & $<0.05$ \\
\hline SdrE & $10 / 13(77 \%)$ & $3 / 10(30 \%)$ & $2.0,2.5^{\mathrm{b}}$ & $11,21^{\mathrm{c}}$ & - \\
\hline
\end{tabular}

${ }^{a}$ Peak IgG level was not reached for FnbpA in patient 2, FnbpA and IsdA in patient 5, Efb in patient 11, and Efb, ClfB, SdrD, and SdrE in patient 13; therefore, these data were excluded

${ }^{\mathrm{b}}$ Absolute fold increase in IgG level

${ }^{\mathrm{c}}$ Absolute number of days until peak level

${ }^{\mathrm{d}} p$-values $<0.05$ (by the Wilcoxon matched-pairs signed-rank test) were considered to be statistically significant

\section{Discussion}

By using multiple, longitudinally collected serum samples, we were able to show that each bacteremic patient develops a unique $S$. aureus-specific immune response after infection. In each bacteremic patient, the $S$. aureus proteins to which the antibody response was directed differed and the height and number of days to reach peak antibody level differed. Therefore, it seems unlikely that a vaccine based on a single staphylococcal component will be effective. There are several possible explanations for the variability of the antistaphylococcal immune response in bacteremic patients. First, it may be the result of the genetic diversity of the $S$. aureus strains which caused the bacteremia [30]. Secondly, the variability might be due to different staphylococcal protein expression and/or selective protein recognition by the immune system in different patients. By way of illustration, although patients 4 and 5 were infected with PFGE-identical $S$. aureus strains with similar virulence genes, the antibody responses were very different (Fig. 1 and Table 2). The observed variability in antibody response might also be caused by the difference in the time of onset of the bacteremia, which is difficult to determine accurately for patients with an origin of bacteremia other than catheterrelated. Finally, colonization, the number and severity of preceding infections, the level of immunity, and the ability to mount an immune response probably also contribute to the development of the antistaphylococcal humoral immune response after bacteremia [31].

Although the antistaphylococcal immune response after infection is a unique personal characteristic, IsdA is immunogenic and, therefore, produced by $S$. aureus in nearly all bacteremic patients. IsdA interacts with and binds to fibrinogen and fibronectin of human cells [32], and is involved in the adherence of $S$. aureus to human desquamated nasal epithelial cells [33]. Furthermore, IsdA is required for nasal colonization in the cotton rat model [33]. Antibodies reactive to IsdA enhanced the killing of $S$.

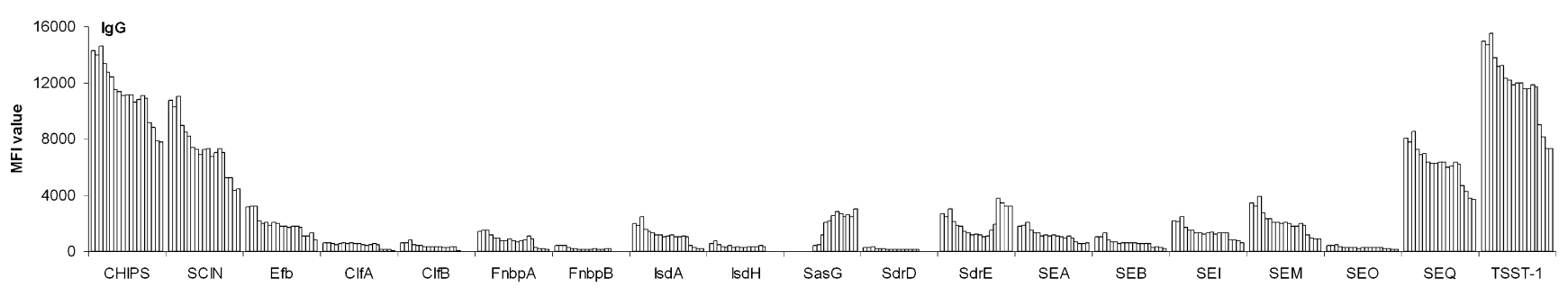

Fig. 4 Course of IgG levels directed to 19 S. aureus proteins in a 5-day-old bacteremic newborn (patient 14). Each bar represents a serum sample on a separate day. The time period between the first and last serum sample is 32 days 
aureus by the antimicrobial peptide apolactoferrin in vitro [34]. Since vaccines should contain multiple components that are expressed in vivo in many, if not all, patients, it seems that IsdA is an interesting target for inclusion in a multicomponent vaccine [35].

In 23 of $179(12.8 \%)$ observed increases, a rise in the antistaphylococcal antibody level was found while the corresponding gene was not detected in the $S$. aureus isolate. Increasing anti-TSST-1, anti-SEB, and anti-FnbpB antibody levels in the absence of tst, seb, and $f n b B$ genes were documented most frequently (Table 2). This might be the result of immunological cross-reactivity. In earlier studies, it was shown that anti-SEB cross-reacts with antiSEC1 [36, 37]. Furthermore, it was shown that anti-TSST-1 also has cross-inhibitory activity against SEA and SEB [38, 39]. However, the relative binding affinity was 1,000 -fold lower for SEA than for TSST-1 and, therefore, this does not seem to be clinically relevant. Another explanation might be that the antibodies are secreted by plasma cells that are mobilized from their survival niche in the bone marrow by competition with newly generated plasma blasts [40]. Knowledge on non-specific antibody binding should be increased, however.

In summary, bacteremic patients usually carry a PFGEidentical S. aureus strain at multiple sites. Each bacteremic patient develops a unique immune response directed against different $S$. aureus proteins. Therefore, a vaccine based on a single antigenic component is not likely to be effective. The surface protein IsdA is immunogenic and, therefore, produced by $S$. aureus in nearly all bacteremic patients. This suggests that IsdA might be a useful component of a multivalent staphylococcal vaccine.

Acknowledgments We thank our colleagues from the Department of Clinical Chemistry, Erasmus MC, Rotterdam, The Netherlands, for their help with collecting the serum samples. We thank Prof. Dr. Barbara Bröker and Dr. Silva Holtfreter for their useful comments.

Open Access This article is distributed under the terms of the Creative Commons Attribution Noncommercial License which permits any noncommercial use, distribution, and reproduction in any medium, provided the original author(s) and source are credited.

\section{References}

1. Pittet D, Wenzel RP (1995) Nosocomial bloodstream infections. Secular trends in rates, mortality, and contribution to total hospital deaths. Arch Intern Med 155(11):1177-1184

2. von Eiff C, Becker K, Machka K, Stammer H, Peters G (2001) Nasal carriage as a source of Staphylococcus aureus bacteremia. Study Group. N Engl J Med 344(1):11-16

3. Wertheim HF, Vos MC, Ott A, van Belkum A, Voss A, Kluytmans JA, van Keulen PH, Vandenbroucke-Grauls CM, Meester MH, Verbrugh HA (2004) Risk and outcome of nosocomial Staphylo- coccus aureus bacteraemia in nasal carriers versus non-carriers. Lancet 364(9435):703-705

4. Jensen AG, Wachmann CH, Poulsen KB, Espersen F, Scheibel J, Skinhøj P, Frimodt-Møller N (1999) Risk factors for hospitalacquired Staphylococcus aureus bacteremia. Arch Intern Med 159 (13):1437-1444

5. Fowler VG Jr, Olsen MK, Corey GR, Woods CW, Cabell CH, Reller LB, Cheng AC, Dudley T, Oddone EZ (2003) Clinical identifiers of complicated Staphylococcus aureus bacteremia. Arch Intern Med 163(17):2066-2072

6. El-Ahdab F, Benjamin DK Jr, Wang A, Cabell $\mathrm{CH}$, Chu VH, Stryjewski ME, Corey GR, Sexton DJ, Reller LB, Fowler VG Jr (2005) Risk of endocarditis among patients with prosthetic valves and Staphylococcus aureus bacteremia. Am J Med 118(3):225-229

7. Wang A, Athan E, Pappas PA, Fowler VG Jr, Olaison L, Paré C, Almirante B, Muñoz P, Rizzi M, Naber C, Logar M, Tattevin P, Iarussi DL, Selton-Suty C, Jones SB, Casabé J, Morris A, Corey GR, Cabell CH (2007) Contemporary clinical profile and outcome of prosthetic valve endocarditis. JAMA 297(12):1354-1361

8. Fowler VG Jr, Miro JM, Hoen B, Cabell CH, Abrutyn E, Rubinstein E, Corey GR, Spelman D, Bradley SF, Barsic B, Pappas PA, Anstrom KJ, Wray D, Fortes CQ, Anguera I, Athan E, Jones P, van der Meer JT, Elliott TS, Levine DP, Bayer AS (2005) Staphylococcus aureus endocarditis: a consequence of medical progress. JAMA 293(24):3012-3021

9. Lautenschlager S, Herzog C, Zimmerli W (1993) Course and outcome of bacteremia due to Staphylococcus aureus: evaluation of different clinical case definitions. Clin Infect Dis 16(4):567573

10. Raad II, Sabbagh MF (1992) Optimal duration of therapy for catheter-related Staphylococcus aureus bacteremia: a study of 55 cases and review. Clin Infect Dis 14(1):75-82

11. Lowy FD (1998) Staphylococcus aureus infections. N Engl J Med 339(8):520-532

12. Smith TL, Pearson ML, Wilcox KR, Cruz C, Lancaster MV, Robinson-Dunn B, Tenover FC, Zervos MJ, Band JD, White E, Jarvis WR (1999) Emergence of vancomycin resistance in Staphylococcus aureus. Glycopeptide-Intermediate Staphylococcus aureus Working Group. N Engl J Med 340:493-501

13. Boucher HW, Talbot GH, Bradley JS, Edwards JE, Gilbert D, Rice LB, Scheld M, Spellberg B, Bartlett J (2009) Bad bugs, no drugs: no ESKAPE! An update from the Infectious Diseases Society of America. Clin Infect Dis 48(1):1-12

14. Wertheim HF, Melles DC, Vos MC, van Leeuwen W, van Belkum A, Verbrugh HA, Nouwen JL (2005) The role of nasal carriage in Staphylococcus aureus infections. Lancet Infect Dis 5(12):751-762

15. Harmsen D, Claus H, Witte W, Rothgänger J, Claus H, Turnwald D, Vogel U (2003) Typing of methicillin-resistant Staphylococcus aureus in a university hospital setting by using novel software for spa repeat determination and database management. J Clin Microbiol 41(12):5442-5448

16. Verkaik NJ, de Vogel CP, Boelens HA, Grumann D, Hoogenboezem T, Vink C, Hooijkaas H, Foster TJ, Verbrugh HA, van Belkum A, van Wamel WJ (2009) Anti-staphylococcal humoral immune response in persistent nasal carriers and noncarriers of Staphylococcus aureus. J Infect Dis 199(5):625-632

17. Foster TJ, Höök M (1998) Surface protein adhesins of Staphylococcus aureus. Trends Microbiol 6(12):484-488

18. O’Brien LM, Walsh EJ, Massey RC, Peacock SJ, Foster TJ (2002) Staphylococcus aureus clumping factor B (ClfB) promotes adherence to human type I cytokeratin 10: implications for nasal colonization. Cell Microbiol 4(11):759-770

19. Balaban N, Rasooly A (2000) Staphylococcal enterotoxins. Int J Food Microbiol 61(1):1-10

20. Jongerius I, Köhl J, Pandey MK, Ruyken M, van Kessel KP, van Strijp JA, Rooijakkers SH (2007) Staphylococcal complement 
evasion by various convertase-blocking molecules. J Exp Med 204(10):2461-2471

21. Peacock SJ, Moore CE, Justice A, Kantzanou M, Story L, Mackie K, O’Neill G, Day NP (2002) Virulent combinations of adhesin and toxin genes in natural populations of Staphylococcus aureus. Infect Immun 70(9):4987-4996

22. van Leeuwen WB, Melles DC, Alaidan A, Al-Ahdal M, Boelens HA, Snijders SV, Wertheim H, van Duijkeren E, Peeters JK, van der Spek PJ, Gorkink R, Simons G, Verbrugh HA, van Belkum A (2005) Host- and tissue-specific pathogenic traits of Staphylococcus aureus. J Bacteriol 187(13):4584-4591

23. Tristan A, Ying L, Bes M, Etienne J, Vandenesch F, Lina G (2003) Use of multiplex PCR to identify Staphylococcus aureus adhesins involved in human hematogenous infections. J Clin Microbiol 41 (9):4465-4467

24. Jarraud S, Mougel C, Thioulouse J, Lina G, Meugnier H, Forey F, Nesme X, Etienne J, Vandenesch F (2002) Relationships between Staphylococcus aureus genetic background, virulence factors, $a g r$ groups (alleles), and human disease. Infect Immun 70 (2):631-641

25. Holtfreter S, Bauer K, Thomas D, Feig C, Lorenz V, Roschack K, Friebe E, Selleng K, Lövenich S, Greve T, Greinacher A, Panzig B, Engelmann S, Lina G, Bröker BM (2004) egc-Encoded superantigens from Staphylococcus aureus are neutralized by human sera much less efficiently than are classical staphylococcal enterotoxins or toxic shock syndrome toxin. Infect Immun 72 (7):4061-4071

26. van Wamel WJ, Rooijakkers SH, Ruyken M, van Kessel KP, van Strijp JA (2006) The innate immune modulators staphylococcal complement inhibitor and chemotaxis inhibitory protein of Staphylococcus aureus are located on beta-hemolysin-converting bacteriophages. J Bacteriol 188(4):1310-1315

27. Melles DC, van Leeuwen WB, Snijders SV, Horst-Kreft D, Peeters JK, Verbrugh HA, van Belkum A (2007) Comparison of multilocus sequence typing (MLST), pulsed-field gel electrophoresis (PFGE), and amplified fragment length polymorphism (AFLP) for genetic typing of Staphylococcus aureus. J Microbiol Methods 69(2):371-375

28. Martins TB, Augustine NH, Hill HR (2006) Development of a multiplexed fluorescent immunoassay for the quantitation of antibody responses to group A streptococci. J Immunol Methods 316(1-2):97-106

29. Verkaik N, Brouwer E, Hooijkaas H, van Belkum A, van Wamel W (2008) Comparison of carboxylated and Penta-His micro- spheres for semi-quantitative measurement of antibody responses to His-tagged proteins. J Immunol Methods 335(1-2):121-125

30. Lindsay JA, Holden MT (2004) Staphylococcus aureus: superbug, super genome? Trends Microbiol 12(8):378-385

31. Holtfreter S, Nguyen TT, Wertheim H, Steil L, Kusch H, Truong QP, Engelmann S, Hecker M, Völker U, van Belkum A, Bröker BM (2009) Human immune proteome in experimental colonization with Staphylococcus aureus. Clin Vaccine Immunol 16 (11):1607-1614

32. Clarke SR, Wiltshire MD, Foster SJ (2004) IsdA of Staphylococcus aureus is a broad spectrum, iron-regulated adhesin. Mol Microbiol 51(5):1509-1519

33. Clarke SR, Brummell KJ, Horsburgh MJ, McDowell PW, Mohamad SA, Stapleton MR, Acevedo J, Read RC, Day NP, Peacock SJ, Mond JJ, Kokai-Kun JF, Foster SJ (2006) Identification of in vivo-expressed antigens of Staphylococcus aureus and their use in vaccinations for protection against nasal carriage. J Infect Dis 193(8): 1098-1108

34. Clarke SR, Foster SJ (2008) IsdA protects Staphylococcus aureus against the bactericidal protease activity of apolactoferrin. Infect Immun 76(4):1518-1526

35. Otto M (2008) Targeted immunotherapy for staphylococcal infections: focus on anti-MSCRAMM antibodies. BioDrugs 22(1):27-36

36. Hynes WL, Weeks CR, Iandolo JJ, Ferretti JJ (1987) Immunologic cross-reactivity of type A streptococcal exotoxin (erythrogenic toxin) and staphylococcal enterotoxins $\mathrm{B}$ and $\mathrm{C} 1$. Infect Immun 55(3):837-838

37. Thompson NE, Ketterhagen MJ, Bergdoll MS (1984) Monoclonal antibodies to staphylococcal enterotoxins B and C: crossreactivity and localization of epitopes on tryptic fragments. Infect Immun 45(1):281-285

38. Kum WW, Chow AW (2001) Inhibition of staphylococcal enterotoxin A-induced superantigenic and lethal activities by a monoclonal antibody to toxic shock syndrome toxin-1. J Infect Dis 183(12):1739-1748

39. Pang LT, Kum WW, Chow AW (2000) Inhibition of staphylococcal enterotoxin B-induced lymphocyte proliferation and tumor necrosis factor alpha secretion by MAb5, an anti-toxic shock syndrome toxin 1 monoclonal antibody. Infect Immun 68(6):3261-3268

40. Odendahl M, Mei H, Hoyer BF, Jacobi AM, Hansen A, Muehlinghaus G, Berek C, Hiepe F, Manz R, Radbruch A, Dörner T (2005) Generation of migratory antigen-specific plasma blasts and mobilization of resident plasma cells in a secondary immune response. Blood 105(4):1614-1621 